\title{
Efficiency of Production of Biogas from Different Non Edible Oil Cakes in Hassan District, Karnataka, India
}

\author{
C. Haleshi ${ }^{1}$ *, Bhavishya ${ }^{2}$, Sreeram N. Hegde ${ }^{1}$, Balakrishna Gowda ${ }^{1}$, \\ K. T. Prasanna ${ }^{1}$, A. C. Girish ${ }^{1}$, Babitha Bora ${ }^{3}$ and Navin Sharma ${ }^{3}$ \\ ${ }^{1}$ Madenur Department of Studies in Botany, Davangere University, Davanagere, India \\ ${ }^{2}$ Central Plantation Crops Research Institute (CPCRI) Regional Station, Vittal, India \\ ${ }^{3}$ Department of Horticulture, Government of Karnataka, Udupi, India \\ *Corresponding author
}

\section{A B S T R A C T}

Keywords

Biogas, Biofuel species, Oil seed cakes, Cow dung,

Biofuel Park

Hassan

Article Info

Accepted:

12 January 2021

Available Online:

10 February 2021
Oil seed cakes are the potential source for biogas production and this is the better way to dispose large quantity of oil seed cakes from biofuel industry. This study was conducted in the villages of Hassan district in the farmers houses, it has important role in the future energy supply from biomasses like oil cakes and cow dung and this is the way to saving of fuel wood and reduce the pressure on forests. Pongamia, Bassia and Calophyllum are three major species growing in Karnataka state and produced lot of oil seed cakes. Calophyllum, Simarouba, Jatropha, Pongamia and Bassia seed cakes were used in the experiments, all these five species are the best source for biogas production, among five Calophyllum, Pongamia and Bassia shown good performance. The spent slurry has rich in nutrients as compared to cow dung this can be used as manure.

\section{Introduction}

The objective of the United Nations Climate Change Conference held at Paris November, 2015 is to achieve to set a goal of limiting global warming to less than 2 degree Celsius $\left({ }^{\circ} \mathrm{C}\right)$ compared to pre-industrial levels. To meet this new challenge we should increase the use of renewable energy and minimize the use of petroleum products and to address the great concern with the environment problems associated with $\mathrm{CO}_{2}, \mathrm{NO}_{\mathrm{x}}$ and $\mathrm{SO}_{\mathrm{x}}$ emissions resulting from the rising use of fossil fuels more attention is being paid to renewable energy, especially biomass energy (Mangut et al., 2006 and Goran et al., 2003).

In India the biofuel industry is slowly developing and lot of byproducts from the industry especially oil cakes needs proper utilization. Oil cakes are rich in proteins, carbohydrates, fatty acids, etc. At present biofuels is costlier than petroleum fuels as byproducts are not used properly and are not getting proper price. If byproducts get suitable value, then the biofuel prices will come down 
and industry will prosper. Hence research should concentrate on utilization and value addition of byproducts of biofuels (Bertil et al., 2004). During oil extraction from oil seeds the oil cake is produced as byproduct and it is the good source of biogas production and they have good percentage of NPK (Table $2)$. The farmers produce biogas generally from cow dung slurry and it is the main source, which results in less production of gas compared to cow dung slurry mixed with oil seed cakes which increase the production of biogas (Isci and Demirer, 2007; Deepak Kumar et al., 2013; Chandra et al., 2012; Staubman et al., 1997). It is experimentally proved and still research works are going on different oil cakes throughout the world on different aspects like biotechnological applications of oil cakes (Sumitra et al., 2007), industrial applications of Jatropha curcas (Ashwani Kumar et al., 2008), production of methane gas from Jatropha and Pongamia oil cake (Chandra et al., 2012), enhancement of methane production from sunflower oil cakes by dilute acid pretreatment (Florian et al., 2013) and Methane generation through anaerobic digestion from Jatropha and Pongamia cake (Vijay et al., 2008). Jasvinder Singh and Sai $\mathrm{Gu}$ critically discussed on conversion of biomass to energy in Indian scenario (Jasvinder and Sai, 2010), serial digesters investigated and optimize biogas production from manure (Prasad et al., 2009), quantitative evaluation of biogas production from methanogens (Walker et al., 2009), Jatropha cake with Buffalo dung (Shilpkar et al., 2009), biomethanation process of Jatropha and Pongamia oil cakes and their co-digested substrates (Shilpkar et al., 2009). Still the information is inadequate to understand the biogas production of cakes.

Biomass is abundant in annual production, with a geographically widespread distribution in the world (Kaygusuz, 2004; Matti Parikka,
2004). Biomass is the fourth largest source of energy in the world, accounting for about $15 \%$ of the world's primary energy consumption and about $38 \%$ of the primary energy consumption in developing countries (Sevgi, 2008).

India is a tropical country blessed with rich biodiversity with favourable climate and soil. There are 287 oil yielding species documented in India (Anonymous, 2007), it includes edible and non edible oil seeds. As per the biofuel policy edible oil cakes should not used for biogas/biofuel production, it should not come in the way of food security. Oil cakes have been in use for feed applications to poultry, fish and swine industry. Being rich in protein, some of these have also been considered for food supplementation (Sumitra et al., 2007). South India particularly Karnataka state has 130 oil yielding species (Jaivika Indana Kannada booklet, 2007). Among 130 species Biofuel Park Hassan has selected ten local species and promoting these species in the farmer's field's viz. bunds, waste lands, ravines, community lands, avenue planting in Hassan district, Karnataka state. The ten non-edible tree species like Pongamia pinnata, Azadirachta indica, Jatropha curcas, Bassia latifolia, Simarouba glauca, Calophyllum inophyllum, Aphanamixis polystachya, Mesua ferrea, Hevea braziliensis and Alurites moluccana. In Karnataka state Pongamia pinnata, Azadirachta indica and Bassia latifolia are the three major oil yielding species and the estimated yield about 2.9 lakh tons/year (Anonymous, 2003). It is a huge source of bioenergy. Generally non edible oil cakes are used as manure, but only small number of farmers are using the oil cakes as manure due to lack of awareness and high prices. Because of this large quantity of oil cakes of Pongamia pinnata, Azadirachta indica, Bassia latifolia, Simarouba glauca, Jatropha curcas, Calophyllum inophyllum are available 
and can be used for biofuel production in the state (Nagamani and Ramaswamy, 1999). Keeping this point in view and to motivate the farmers to use the oil cakes for production of biogas an experiment was laid at Biofuel park Madenur with the main objective of farmers do practically in their own houses get the experience and understand the utility, importance and efficiency of oil cakes in biogas production.

In this way Biofuel Park, Hassan, University of Agricultural Sciences Bangalore in collaboration with ICRAF (World Agroforestry Center) Nairobi has taken initiation to establish Biogas units at Kinnarahalli, Halenahalli, Malligevalu, Jyothimallapura, Nagenahalli, Talalur, Talaluthore, Bilagunda and Ballekere with the intention of creating smokeless villages in the Hassan district.

\section{Materials and Methods}

Hassan district is one among the 30 district of Karnataka state, India and is located between $12^{0} 31^{1}$ and $13^{0} 33^{1} \mathrm{~N}$ latitude and $75^{0} 33^{1}-$ $76^{0} 38^{1}$ E longitudes. Following villages of Hassan district were selected and experiments were conducted in Kinnarahalli, Malligevalu, Bilagunda and Ballekere (Map-1), nine farmers were selected who had Gobar gas units (Table 1). These farmers were provided with required quantity of different oil seed cakes, note books and given instruction to them about the uses of oil cakes. First two day's normal cow dung slurry was used and observations on cooking of gas for cooking in minutes was recorded and third day onwards oil cake was used along with cow dung slurry and observations were recorded and proportion of the cake is based on their size of Gobar gas units. Before application the cakes were soaked in water (1:1) for 3-4 hours to mix well with cow dung slurry. Oil seed cakes like Calophyllum inophyllum, Simarouba glauca, Jatropha curcas, Pongamia pinnata, and Bassia latifolia were produced in Biofuel Park, Hassan. Daily observations were recorded on the basis of cooking time (minutes) the starting and ending time until complete usage and later the minutes were converted into volume $\left(\mathrm{m}^{3}\right)$. Calophyllum cake was used by four farmers, one farmer Simarouba cake, one farmer Jatropha cake, two farmers Pongamia cake and one farmer used Bassia cake (Table 1).

The mixing ratio of Cow dung and water is $1: 1$ (23) and oil cake water ratio is $1: 1$. The cow dung and oil cakes were mixed in different ratio for different cakes (Table 3). Treatment details with cake used and name of the farmers are as follows.

\section{Cake treatments}

\section{Calophyllum cake treatment details}

Girish B.T, Bilagunda, Kattaya Hobli: First two days only cow dung was applied and from third day onwards $2 \mathrm{~kg}$ of Calophyllum cake was applied along with $15 \mathrm{~kg}$ cow dung up to $12^{\text {th }}$ day.

Yogachar, Malligevalu, Kattaya Hobli: First two days only cow dung was applied, from $3^{\text {rd }}$ day onwards up to $13^{\text {th }}$ day 2 $\mathrm{kg}$ of Calophyllum cake and $8 \mathrm{~kg}$ cow dung was applied.

Manjegowda, Malligevalu, Kattaya Hobli: First two days only cow dung was applied, on $3^{\text {rd }}$ day onwards up to $12^{\text {th }}$ days $2 \mathrm{~kg}$ of Calophyllum cake and 8 $\mathrm{kg}$ of cow dung was applied in the morning.

Shivalingappa, Kinnarahalli, Halekote hobli: First two days only cow dung was applied, on $3^{\text {rd }}$ day onwards up to $7^{\text {th }}$ day daily $2 \mathrm{~kg}$ of Calophyllum cake was added with $6 \mathrm{~kg}$ cow dung in the morning. 


\section{Simarouba cake treatment details}

Murthy, Bilagunda, Kattaya hobli, Hassan: First two days only cow dung was applied like their regular practice, on $3^{\text {rd }}$ day onwards up to $12^{\text {th }}$ day daily $2 \mathrm{~kg}$ of Simarouba cake was added with $6 \mathrm{~kg}$ cow dung in the morning.

\section{Jatropha cake treatment details}

Devarajegowda, Ballekere, Hassan: First two days only cow dung was applied, from $3^{\text {rd }}$ day onwards up to $7^{\text {th }}$ day daily $2 \mathrm{~kg}$ of Jatropha cake was added with $6 \mathrm{~kg}$ cow dung in the morning.

\section{Pongamia cake treatment details}

Shivanna, Malligevalu, Kattaya hobli: First two days only cow dung was applied, from 3rd day onwards up to $11^{\text {th }}$ day daily $1 \mathrm{~kg}$ of Pongamia cake was added with $5 \mathrm{~kg}$ cow dung in the morning.

Basavalingappa, Kinnarahalli, Halekote hobli: First two days only cow dung was applied, from $3^{\text {rd }}$ day onwards up to 12 days daily $1 \mathrm{~kg}$ of Pongamia cake was added with $5 \mathrm{~kg}$ of cow dung in the morning.

\section{Bassia cake treatment details}

Puttegowda, Malligevalu, Kattaya hobli: First two days only cow dung was applied, on $3^{\text {rd }}$ day onwards up to $7^{\text {th }}$ day daily $2 \mathrm{~kg}$ of Bassia cake was added with $5 \mathrm{~kg}$ cow dung in the morning.

\section{Conversion of minutes to volume $\left(\mathrm{m}^{3}\right)$}

The volume was calculated by using $\mathrm{D}^{2} \mathrm{H}$, here $\mathrm{D}$ is diameter of the biogas unit and $\mathrm{H}$ is height (gas accumulated part) of the biogas unit. Measuring the circumference and height of the biogas unit, diameter was calculated by using $\mathrm{C} / \pi, \mathrm{C}$ is circumference, and it is divided by $\pi$ value. Recorded the burning minutes from known volume of the unit and this can be applied to all units and minutes were converted into volume in $\mathrm{m}^{3}$.

\section{Results and Discussion}

\section{Calophyllum cake treatment}

The results of cooking hours of oil cakes in farmers units are furnished, it is observed that Calophyllum cake and Cow dung (Girish) shows more production of biogas $\left(2.9 \mathrm{~m}^{3}\right)$ when compared to pure Cow dung $\left(1.82 \mathrm{~m}^{3}\right)$ (Fig. 1), when cow dung mixed with Calophyllum cake increases $1.1 \mathrm{~m}^{3}$ per day is observed (37\%). In First day of application of cake biogas production increases by $16 \%$ and gradually reaches to $37 \%$ on $5^{\text {th }}$ day. In another experiment (Yogachar) the performance of cow dung was $1.02 \mathrm{~m}^{3}$ and after application of Calophyllum oil cake showed $1.45 \mathrm{~m}^{3}$ gas production and it increase $27 \%$ gas production. Here after application of cake the gas production immediately increases by $12.5 \%$ and gradually reaches $27 \%$ with time. Manjegowda experiment shown $1 \mathrm{~m}^{3}$ of gas production in Cow dung and $1.34 \mathrm{~m}^{3}$ gas production when applied Calophyllum cake, it increases $25.5 \%$ of production.

After application of cake the gas production increases by $12 \%$ and gradually it reaches $25.5 \%$. The same experiment of Shivalingappa shown cow dung $0.9 \mathrm{~m}^{3}$ while after application of Calophyllum cake the cooking minutes was $1.15 \mathrm{~m}^{3}$ (increase of $22.5 \%$ ). After application of cake the gas production immediately increases by $10 \%$ and gradually increases and reaches to $22.5 \%$. Even though biodegradable organic matter (cow dung) is a sole feedstock in anaerobic digestion, the digestion process tends to fail without the addition of external nutrients and buffering agents (oil cake) (24). 


\section{Simarouba cake treatment}

The cow dung production resulted in $0.91 \mathrm{~m}^{3}$ gas whereas Simarouba cakes with cow dung resulted in $1.12 \mathrm{~m}^{3}$ (Fig. 2), which shows sudden increase in production of $14 \%$ in the next day, when applied eighteen days and gas production is increasing gradually reaches to $23.5 \%$, but in the beginning sudden increase might be due to over activation of Methanogens (Fig. 2).

\section{Jatropha cake treatment}

The gas production from cow dung recorded $0.871 \mathrm{~m}^{3}$ whereas after application of Jatropha cake the gas production increased to $1.211 \mathrm{~m}^{3}$. After application of cake the production increases by $12 \%$ in the beginning days and the application of cake for five days it gradually increases and reaches $28 \%$ (Fig. $3)$.

Table.1 List of farmers using oil cake with cow dung in Gobar gas units

\begin{tabular}{|l|l|l|l|}
\hline Sl.No. & Cake used & Name of Farmer & Village, Taluk \& District \\
\hline 1 & $\begin{array}{l}\text { Calophyllum inophyllum } \\
\text { (Surahonne) }\end{array}$ & Girish & Bilagunda, Hassan, Hassan \\
\hline 2 & $\begin{array}{l}\text { Calophyllum inophyllum } \\
\text { (Surahonne) }\end{array}$ & Yogachar & Malligevalu, Hassan, Hassan \\
\hline 3 & $\begin{array}{l}\text { Calophyllum inophyllum } \\
\text { (Surahonne) }\end{array}$ & Manjegowda & Malligevalu, Hassan, Hassan \\
\hline 4 & $\begin{array}{l}\text { Calophyllum inophyllum } \\
\text { (Surahonne) }\end{array}$ & Shivalingappa & Kinnarahalli, Holenarasipura, Hassan \\
\hline 5 & $\begin{array}{l}\text { Simarouba glauca } \\
\text { (Simarouba) }\end{array}$ & Murthy & Bilagunda, Hassan, Hassan \\
\hline 6 & $\begin{array}{l}\text { Jatropha curcas } \\
\text { (Jatropha) }\end{array}$ & Devarajegowda & Ballekere, Hassan, Hassan \\
\hline 7 & $\begin{array}{l}\text { Pongamia pinnata } \\
\text { (Honge) }\end{array}$ & Shivanna & Malligevalu, Hassan, Hassan \\
\hline 8 & $\begin{array}{l}\text { Pongamia pinnata } \\
\text { (Honge) }\end{array}$ & Basavalingappa & Kinnarahalli, Holenarasipura, Hassan \\
\hline 9 & Bassia latifolia (Hippe) & Puttegowda & Malligevalu, Hassan, Hassan \\
\hline
\end{tabular}

Table.2 Nutrient content of oil cakes

\begin{tabular}{|l|l|c|c|c|c|c|c|}
\hline $\begin{array}{c}\text { Sl. } \\
\text { no }\end{array}$ & \multicolumn{1}{|c|}{ Oil Cakes } & $\mathbf{p H}$ & $\begin{array}{c}\text { EC } \\
(\mathbf{d s} / \mathbf{m})\end{array}$ & $\begin{array}{c}\text { OC } \\
(\mathbf{\%})\end{array}$ & $\begin{array}{c}\text { Total N } \\
(\mathbf{\%})\end{array}$ & $\begin{array}{c}\text { Total P } \\
(\mathbf{\%})\end{array}$ & $\begin{array}{c}\text { Total K } \\
(\mathbf{\%})\end{array}$ \\
\hline $\mathbf{1}$ & Pongamia & 5.8 & 1.0 & 51.5 & 3.9 & 0.60 & 0.88 \\
\hline $\mathbf{2}$ & Bassia (Mahua) & 4.7 & 1.6 & 51.9 & 1.5 & 0.29 & 0.36 \\
\hline $\mathbf{3}$ & Simarouba & 5.6 & 0.9 & 53.9 & 7.1 & 0.38 & 0.5 \\
\hline $\mathbf{4}$ & Calophyllum & 4.5 & 1.1 & 42.4 & 2.1 & 0.29 & 0.11 \\
\hline
\end{tabular}


Table.3 Oil cake and cow dung proportion and gas production (maximum)

\begin{tabular}{|c|c|c|c|c|}
\hline Name of the cake & $\begin{array}{l}\text { Qty of } \\
\text { CD in Kg }\end{array}$ & $\begin{array}{l}\text { Qty of } \\
\text { OC in Kg }\end{array}$ & $\begin{array}{l}\text { Before application } \\
\text { of Cake (burned } \\
\text { minutes) }\end{array}$ & $\begin{array}{l}\text { After application of } \\
\text { Cake (Maxi.Minutes } \\
\text { burned) }\end{array}$ \\
\hline Calophyllum inophyllum 1) & 15 & 2 & 240 & 380 \\
\hline 2) & 8 & 2 & 135 & 191 \\
\hline 3) & 8 & 2 & 132 & 177 \\
\hline 4) & 6 & 2 & 118 & 152 \\
\hline Simarouba glauca & 6 & 2 & 120 & 155 \\
\hline Jatropha curcas & 6 & 2 & 115 & 160 \\
\hline Pongamia pinnata & 5 & 2 & 90 & 140 \\
\hline 2) & 5 & 2 & 95 & 140 \\
\hline Bassia latifolia & 5 & 2 & 90 & 141 \\
\hline
\end{tabular}

$\mathrm{CD}=$ Cow Dung, $\mathrm{OC}=$ Oil Cake $\&$ Min=Minutes
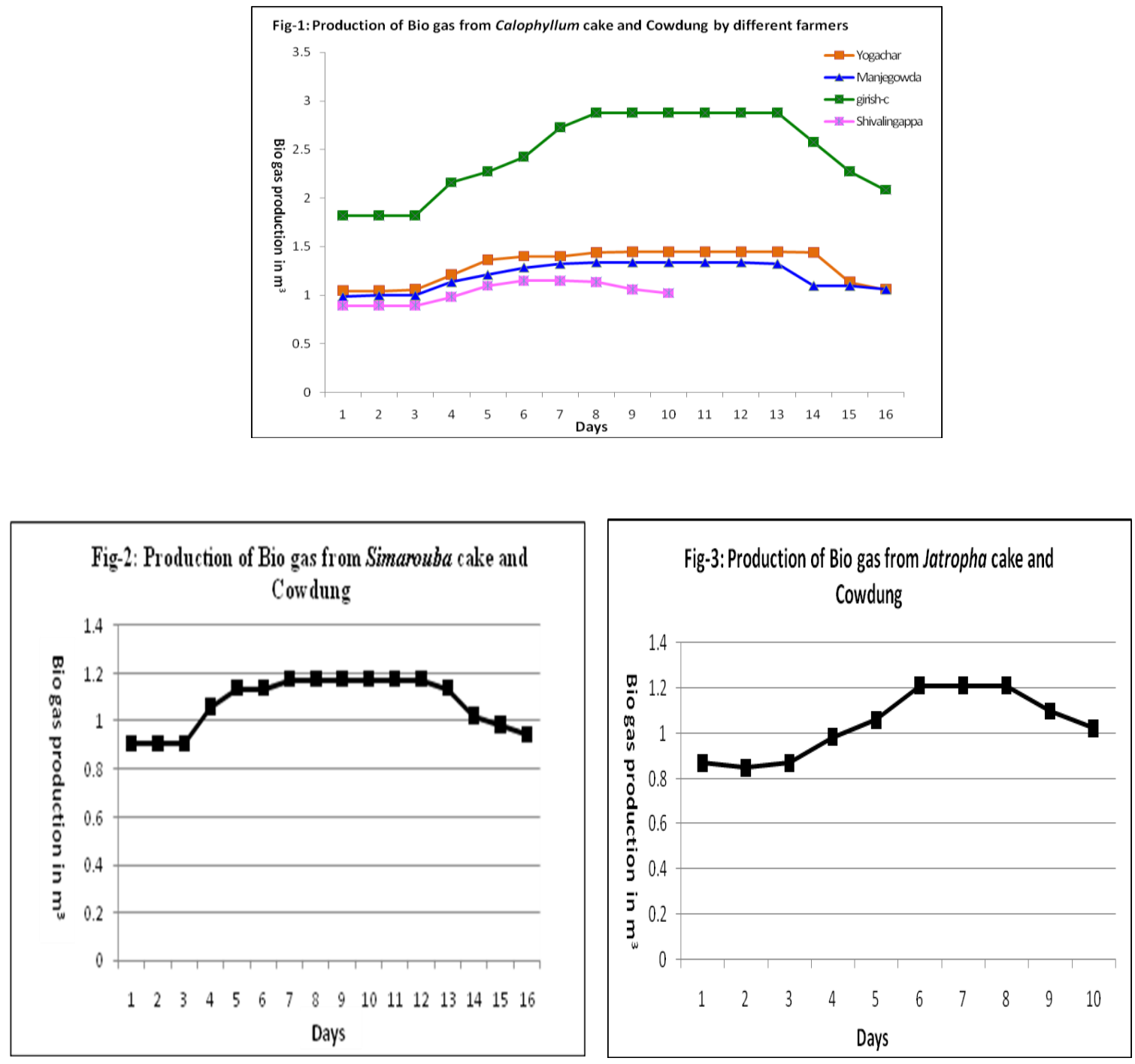

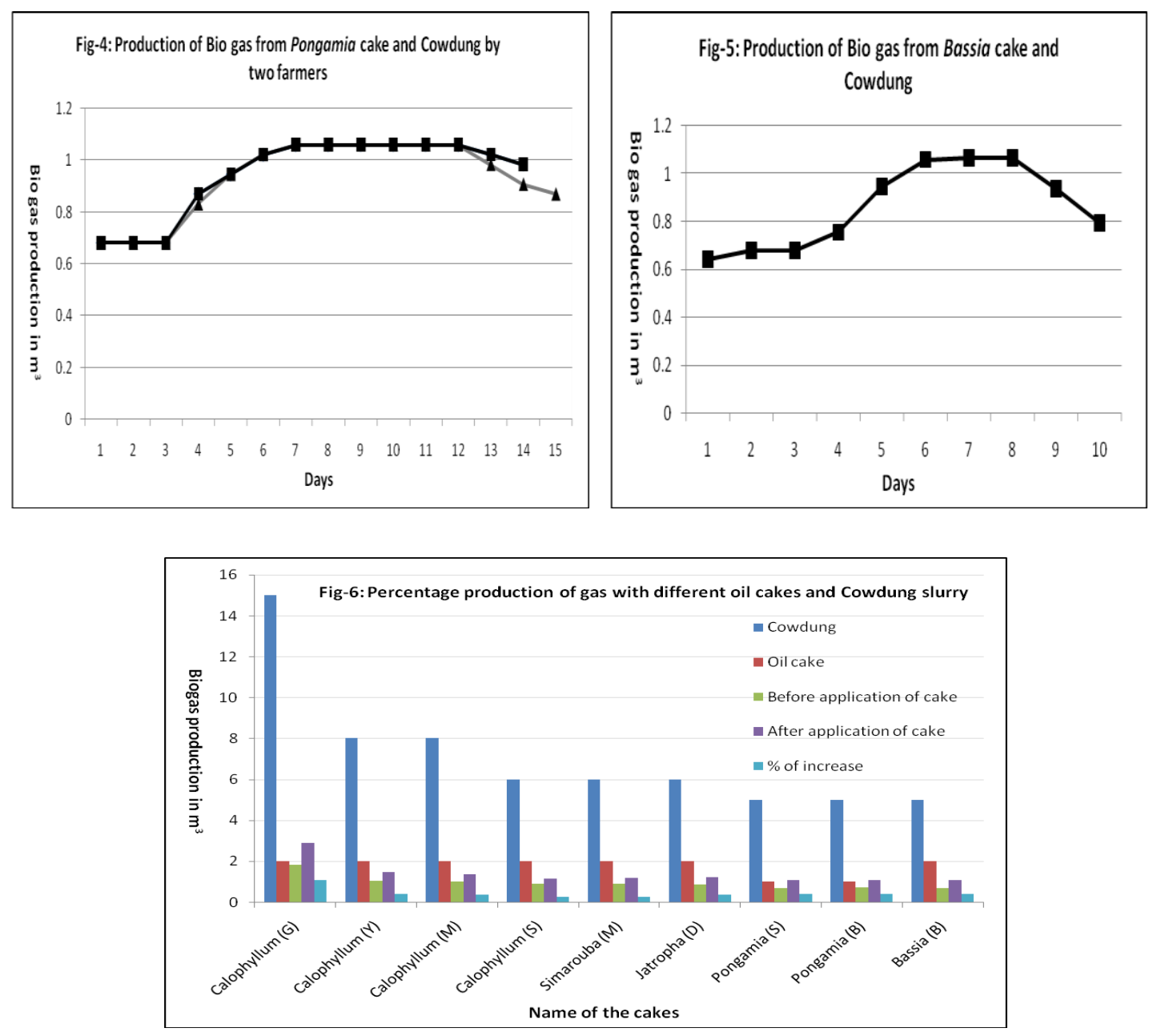

Map.1 Map indicating study villages in the Hassan district, Karnataka, India

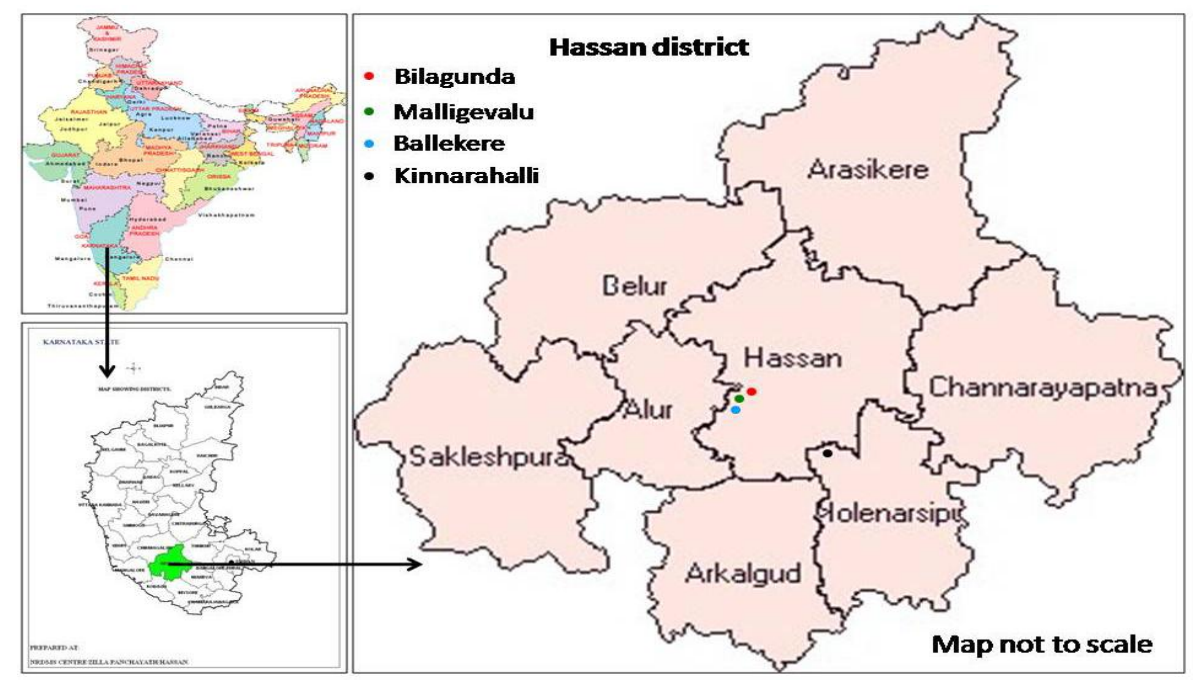




\section{Pongamia cake treatment}

The cow dung production resulted in 0.681 $\mathrm{m}^{3}$ and after application of cake in the first day the production is increases 22\% (first case Shivanna) during application of cake the gas production gradually increases and reaches to $36 \%$ than the cow dung production. After twelve days the gas production slowly reduces. In the second case (Basavalingappa, Kinnarahalli) the gas production in the cow dung resulted in $0.72 \mathrm{~m}^{3}$ gas and after application of cake it increases by $18 \%$ and gradually it increases and reaches maximum to $36 \%$ during the cake application. Here initially the gas production is more due to high activation of methanogens. Gas production gradually increases and reaches to $36 \%$ (Fig. 4).

\section{Bassia cake treatment}

$0.682 \mathrm{~m}^{3}$ of gas was observed during cow dung application, and production increases by $10 \%$ after cake application and gradually it increases and reached to $36.2 \%\left(1.1 \mathrm{~m}^{3}\right.$.)

The production of biogas is varying from one unit to another because the usage of cow dung and cake quantity is varying from unit to unit because the units are of different size. The bigger units need more feed and smaller units need less. In case of Calophyllum oil cake the production of biogas is $37 \%$ in bigger units and lesser production (22\%) in smaller units even though used the same quality of cake. The low production of gas compared to above two might be due to light effect (25) and location of the unit. Gas production in Simarouba is little low when compared to Calophyllum, Pongmia and Bassia cakes may be due to hard coat of the seeds in the cake (26 and 27) even though it has high proteins and fats. The hard coat of the seed not encourages the microbial growth. Jatropha produces $28 \%$ more biogas after mixing with cow dung, it produces little low when compared to Calohyllum, Pongamia and Bassia due to undigested matters in the cake (26). Pongamia cake produces more biogas when compared to Simarouba and Jatropha may be due to presence of high proteins, fats, soft tissue and other components in the cake (28), Pongamia cake shown instant production of biogas (Fig. 4), when compared to the other cakes due to more activation of methanogens the biogas will produces immediately in the next days. Bassia cake also produces more biogas $(36.2 \%)$ even though it has some undigested matter (hard seed coat) again it might be high proteins and fats encourages the microbial growth and more gas will be produced and Bassia cake is the second potential candidate for biogas production after Calophyllum cake.

In conclusion it is evident from this study that oil cakes are the potential source for biogas production. The gas production enhances from $10 \%-37 \%$ from use of different oil cakes. There is variation in gas production from different cakes, but with any oil cakes more gas is produced than use of normal cow dung. Among the oil cakes Calophyllum (37\%) shows best performance might be due to presence of high proteins and fats (55-60\%) in the cake favorable for microbial activity. It is followed by Bassia (36.2\%) and Pongamia (36\%) cakes which have shown good performance again might be due to presence of high proteins and fats. Jatropha cake has shown good gas production might be due to its acidic nature and high percentage of Organic Carbon (OC). Low production recorded from Simarouba cake compared to others might be due to chemical composition of the cake and hard coat of the seed which cannot be digested by the microorganisms. This study indicated that the use of oil cake is very good source for biogas production and it is the answer for rising fuel crisis in India. After biogas production the spent slurry has 
also rich nutrients same as cow dung and oil cakes this can also be used as manure and the anaerobic digestion of oil cakes is the best way to dispose. There is false belief that the spent slurry has less nutrients but lot of studies conducted by Biofuel Park Hassan has proved that the spent slurry has rich in nutrients. If the farmers using more oil cake for their biogas units and produce more gobar gas it automatically reduces the pressure on forests and minimize the uses of LPG's and Kerosene especially in the rural areas it greatly contributes to the savings of foreign exchange, mitigate global warming (29 and 30 ) by carbon reduction and biodiversity conservation.

\section{Acknowledgement}

Authors thankful to ICRAF (World Agroforestry Center, Nairobi, Kenya) for funding the rural energy option project in Hassan district India.

\section{References}

Abubaker, J., Risberg, K. and Pell, M. (2012). Biogas residues as fertilisers - effects on wheat growth and soil microbial activities. Applied Energy 99, 126-134. (to be included in the text)

Akhil Gupta, Ram Chandra, Subbarao PMV and Vijay VK. Kinetics of batch biomethanation process of Jatropha and Pongamia oil cakes and their codigested substrates. Journal of Scientific \& Industrial Research 2009; 68: 624629.

Alyona Zubaryeva, Nicola Zaccarelli, Cecilia Del Giudice, Giovanni Zurlini. Spatially explicit assessment of local biomass availability for distributed biogas production via anaerobic co-digestion e Mediterranean case study. Renewable Energy xxx 2011; 1-10.
Anonymous Data base of Oil yielding plants. Botanic Garden of Indian Republic (BGIR) Botanical Survey of India, Noida 2004; 1-57. (http: bgci.org/garden, 2007).

Anonymous Study on Non-Edible Oil Seeds and Oil Production in Karnataka, Draft Final Report. Environmental Management and Policy Research Institute, Bangalore 2003 (http: Karnataka.gov.in/empri/Documents/No n-edible-oil-seeds-in-karnataka-EMPRI2003-12.pdf)

Ashwani Kumar and Satyawati Sharma. An evaluation of multipurpose oil seed crop for industrial uses (Jatropha curcas L.): A review. Industrial Crops and Products 2008; 28(1): 1-10.

Bertil Wahlund, Jinyue Yan, Mats Westermark. Increasing biomass utilization in energy systems: A comparative study of $\mathrm{CO}_{2}$ reduction and cost for different bioenergy processing options. Biomass and Bioenergy 2004; 26:531-544.

Chandra R, Vijay VK, Subbarao PMV and Khura TK. Production of methane from anaerobic digestion of Jatropha and Pongamia oil cakes. Applied Energy 2012; 93: 148-159.

Deepak Kumar, Nitin Kumar Swarnkar and Vijayakumary P. Biogas Production Potential of Pungam Oil Cake. International Journal of Chem Tech Research 2013; 5(2): 741-746.

Fabiana Passos, Maria Sole, Joan Garcia and Ivet Ferrer. Biogas production from microalgae grown in wastewater: Effect of microwave pretreatment. Applied Energy 2013; 108: 168-175.

Florian Monlau, Eric Latrille, Aline Carvalho Da Costa, Jean-Philippe Steyer and Helene Carrere. Enhancement of methane production from sunflower oil cakes by dilute acid pretreatment. Applied Energy 2013; 102:1105-1113. 
Gonzalez-Fernandez C, Sialve B, Bernet N, Steyer JP. Impact of microalgae characteristics on their conversion to biofuel. Part II: Focus on biomethane production. Biofuels, Bioprod Biorefin 2011; 6(2): 205-18.

Gopi Krishna Kafle, Sang Hun Kim. Anaerobic treatment of apple waste with swine manure for biogas production: Batch and continuous operation. Applied Energy 2013; 103: 61-72.

Goran Berndes, Monique Hoogwijk, and Richard van den Broek. The contribution of biomass in the future global energy supply: a review of 17 studies. Biomass and Bioenergy 2003; 25:1-28.

Isci $\mathrm{A}$ and Demirer GN. Biogas production potential from cotton wastes. Renewable Energy 2007; 32(5): 750757.

Jasvinder Singh and Sai Gu. Biomass conversion to energy in India-A critique. Renewable and Sustainable Energy Reviews 2010; 14: 1367-1378.

Kaygusuz, K. The role of renewables in future energy directions of Turkey. Energ. Sources 2004; 26: 1131-1140.

Mangut V, Sabio E, Ganan J, Gonzalez JF, Ramiro A, Gonzalez CM, Roman S, AlKassir A. Thermogravimetric study of the pyrolysis of biomass residues from tomato processing industry. Fuel Process. Technol. 2006; 87:109-115.

Matti Parikka. Global biomass fuel resources. Biomass and Bioenergy 2004; 27: 613620.

Nagamani B and Ramaswamy K. Biogas production technology: An Indian perspective. Current Science 1999; 77(1): 44-55.

Periyasamy Elaiyaraju and Nagarajan Partha. Biogas production from co-digestion of orange peel waste and jatropha de-oiled cake in an anaerobic batch reactor.
African Journal of Biotechnology 2012; 11(14): 3339-3345.

Prasad Kaparaju, Lars Ellegaard and Irini Angelidaki. Optimisation of biogas production from manure through serial digestion: Lab-scale and pilot-scale studies. Bioresource Technology 2009; 100: 701-709.

Ram Chandra, Virendra K, Vijay, and Parchuri Subbarao MV. A Study on Biogas Generation from Non-edible Oil Seed Cakes: Potential and Prospects in India. The $2^{\text {nd }}$ Joint International Conference on Sustainable Energy and Environment (SEE) November 21-23, 2006 Bangkok, Thailand.

Sevgi Sensoza and Dilek Angin. Pyrolysis of safflower (Charthamus tinctorius L.) seed press cake: Part 1. The effects of pyrolysis parameters on the product yields Bioresource Technology 2008; 99: 5492-5497.

Shilpkar Prateek, Roal Gopal, Shah Mayur and Deepti Shilpkar. Biomethanation potential of Jatropha (Jatropha curcas) cake along with buffalo dung. African Journal of Agricultural Research 2009; 4 (10): 991-995.

Sims R, Schock R, Adegbululgbe A, Fenhann J, Konstantinaviciute I, Moomaw W. Energy supply. In: Metz B, Davidson O, Bosch P, Dave R, Meyer L, editors. Climate change: mitigation. contribution of working group III to the fourth assessment report of the intergovernmental panel on climate change. Cambridge: Cambridge University Press; 2007. p. 322.

Staubman R, Gabriele foidl, Nikolaus Foidl, Georg M Gubitz, Robert M Lafferty, Victoria M Valencia Arbizu and Walter Steiner. Biotechnology for Fuels and Chemicals (Series Applied Biochemistry and Biotechnology) 1997; 63-65:457-467.

Sumitra Ramachandran, Sudheer Kumar 
Singh, Christian Larroche, Carlos Ricardo Soccol and Ashok Pandey. Oil cakes and their biotechnological applications. Bioresource Technology 2007; 98: 2000-2009.

Vijay VK, Chandra R and Subbarao PMV. Production of Methane through Anaerobic Digestion of Jatropha and Pongamia Oil Seed Cakes. The Second International Energy 2030, November 4-5, 2008, Abu Dhabi, UAE.

Vindis PB, Mursec M Janzekovic and Cus F. The impact of mesophilic and thermophilic anaerobic digestion on biogas production. Journal Achievements in Materials and Manufacturing Engineering 2009; 36(2): 192-196.

Walker M, Zhang Y, Heaven S and Banks CJ. Potential errors in the quantitative evaluation of biogas production in anaerobic digestion processes. Bioresource Technology 2009; 100(24): 6339-6346.

\section{How to cite this article:}

Haleshi, C., Bhavishya, Sreeram N. Hegde, Balakrishna Gowda, K. T. Prasanna, A. C. Girish, Babitha Bora and Navin Sharma. 2021. Efficiency of Production of Biogas from Different Non Edible Oil Cakes in Hassan District, Karnataka, India. Int.J.Curr.Microbiol.App.Sci. 10(02): 1316-1326. doi: https://doi.org/10.20546/ijcmas.2021.1002.156 